\title{
Integrating the Digital Paradigm in Higher Education: ICT Training and Skills of University Students in a European Context
}

\author{
Juan David Concepción Rosa a , María Guadalupe Veytia Bucheli ${ }^{\text {b }}$, José \\ Gómez Galán ${ }^{\text {c }}$ \& Eloy López Meneses ${ }^{\text {d }}$.
}

Received: 10 May 2019• Accepted: 21 August 2019

\begin{abstract}
The main objective of this study is to analyse the basic digital skills of university students. A sample of 490 students of two degrees from a Spanish university was used from the 2013/14 to 2016/17 academic year. The methodology is descriptive of a quantitative nature. The data were collected by means of the questionnaire called "Basic digital competences 2.0 of the university students" COBADI® (Registered trademark: 2970648). The statistical analysis provided information on how students use the Internet and digital technologies. Among the results obtained it could be determined that a high percentage of the respondents were connected to the Internet more than 9 hours a week. The most frequently used means of connection is the computer, at home, and the smartphone. A significant finding is that, in the case of men, there is a decrease in time spent on academic tasks in favour of time spent on videogames.
\end{abstract}

Key-words: Digital Literacy, University Education, University Students, Educational Innovation.

\section{Introduction}

The Information and Knowledge Society is a phenomenon that has been impacting human beings for a few decades. It is characterized by Information and Communication Technology (in advance, ICT) that offers people the possibility to access, share and process data, even remotely and in real time

\footnotetext{
${ }^{a}$ Ana G. Méndez University (Puerto Rico-United States), ${ }^{\mathrm{b}}$ Autonomous University of Hidalgo State (Mexico), ${ }^{\mathrm{c}}$ Ana G. Méndez University (Puerto Rico-United States) \& University of Extremadura (Spain), ${ }^{\mathrm{d}}$ Universidad Pablo de Olavide, Seville (Spain). Correspondence: Juan David Concepción Rosa, Escuela de Educación, Universidad Ana G. Méndez (Recinto de Cupey) Avenida Ana G. Mendez, San Juan, 00926, Puerto Rico. jconcepcion14@uagm.edu
} 
(Gutiérrez-Porlán, 2014; Cabero, 2015), are elements of discrimination and exclusion in certain social contexts (Cabero \& Ruiz-Palmero, 2018), which become part of our lives and influence what we know and how we learn (Gómez Galán, 2002 and 2011; Blau \& Shamir-Inbal, 2017; Marathe, 2017). In short, their impact affects all social spheres and especially education.

Within the framework of action of Agenda 2030, the United Nations (UN) has endorsed that young people should adopt flexible skills and competencies that are useful throughout their lives, considering a world that needs greater sustainability and interdependence based on knowledge and ICTs (Delors, 1996; Gómez Galán, 2014; Riis, 2017). Similarly, education policies increasingly advocate for the use of ICTs in and out of the classroom as a support mechanism for teaching and learning. Consequently, training in digital competence among university students is relevant for sustainable citizenship.

Similarly, the evolution of distance education and technological advances constitute an important opportunity to increase access to education and contribute to the fulfilment of international educational commitments. In turn, they have brought about a pedagogical change that fosters and encourages real experiences and activities focused on deeper and more interactive learning (Castao, Duart, \& Teresa, 2015; Gómez Galán, 2017), which is characterized as ubiquitous (Vázquez-Cano, et al., 2013; Atif, Mathew \& Lakas, 2015) invisible (Cobo and Moravec, 2011) or rhizomatic (Bozkurt, et al., 2016; Mbati, 2017). In this sense, the unstoppable explosion and expansion of knowledge calls for the need for lifelong learning as a basic requirement for personal and professional development.

On the other hand, the technology used in sustainable digital learning ecologies has provided a set of benefits and potentialities with respect to traditional methods of content transmission, since they allow for greater significant learning, taking into account the characteristics of each individual (Maquilón, Mirete \& Avilés, 2017), obtaining high indicators of the effectiveness of the process (González-Aldana, Perdomo \& Pascuas, 2017), greater dynamism of learning, greater protagonism of the student in educational action, to acquire basic competencies (Torres \& Kiss, 2016), to facilitate the shared creation of knowledge through learning communities (Romero and Patiño, 2018), to originate a relevant pedagogical change in the training scenarios (Gómez Galán, 2004; Tejada, 2013), to promote the autonomous learning of the students (Kormos, \& Csizer, 2014), to encourage them to be more motivated in their daily tasks (Laskaris, Kalogiannakis \& Heretakis, 2017).

In our study we will focus on digital training as one of the basic competences of the 21 st century citizen, which is considered as one of the main transversal competences of all Spanish universities (GonzálezCalatayud, Román \& Prendes, 2018), in line with the context of the European 
Union in which they are located. In this sense, after carrying out an extensive review and comparison of definitions, Gutiérrez-Porlán (2014, p. 54) understands digital competence as "values, beliefs, knowledge, skills and attitudes to use technologies appropriately, including both computers and different programs and the Internet, which allow and enable the search, access, organization and use of information in order to build knowledge".

Skills training provides a management and development approach to lifelong learning, in which people learn to learn, try to transform the reality in which they are immersed, adapting to social, productive, economic and technological changes (Hernández Pina et. al., 2009). The approach by competences in the Knowledge and Information Society concentrates a different vision in the educational field, the adaptation to the European Higher Education Area (EHEA) has led European universities to a great transformation (Gómez Galán, 2014, Krücken, 2014)

\section{Review of Scientific Literature}

The development that ICTs have experienced on one side and on the other, their overlapping with the educational action, have precipitated that their presence in the classrooms and in the academic life of students, teachers and education professionals, necessarily influenced by them and with the need to use them in their daily work.

Likewise, in today's society, characterized by rapid and profound changes (OECD, 2018), technological advances are continuous and progressive, creating a "digital culture" (Hinostroza, 2017). In other words, it is undeniable that ICTs have occupied a large part of people's lives, reaching different sectors of society, with education being one of the areas where innovations are currently materializing and taking root in the processes of teaching and learning (Rodríguez, Cáceres \& Alonso, 2018). In this sense, experts in ICT, (Cabero \& Barroso, 2018) have recently shown that they have caused a pedagogical change that promotes and encourages real experiences and activities focused on a deeper and more interactive learning.

On the other hand, it should be noted that among the main characteristics of ICT, and which are influenced in the educational field, are ubiquity -since it can be used from any place and at any time- and ergonomics -since it adapts to the specificities of the teaching and learning processes(Fombona \& Pascual, 2017). Moreover, they can be elements of discrimination and exclusion in certain social contexts (Cabero and RuizPalmero, 2018); spaces of collaboration for the development of the creativity of their users and change our way of living and working (Schwab, 2016).

The continuous advance of ICTs in today's Knowledge Society has led to the demand for training in new skills, called 21 st century skills and makes training a crucial element for the proper development of citizenship in this 
new society (Erstad \& Voogt, 2018). In this sense, it is worth highlighting studies on the conceptualization of competition, on its historical background González and Wagenaar (2006) from the European context Tuning, Villa and Poblete (2007) from an intercontinental approach Europe-Latin America, or, San Martín (2010) emphasizing the American continent in general and Chile in particular, and in the Spanish environment, high-lights the research on competition (Prendes, 2010).

In this sense, Durán, Prendes and Gutiérrez (2019) have articulated around the concept of competence the model of key competences of the citizen of the 21 st century (European Commission, 2006) that includes: communication in the mother tongue; competence in mathematics, science and technology; digital competence; learning to learn competence; social and civic competence; entrepreneurship competence; expression competence and cultural awareness. Perhaps the clearest explanation, however, is the metaphor of the knots in Le Boterf (2000): one can know the seafaring knots, and can even be skilful at making knots, but will only be competent if he knows the right knot to solve a given problem situation.

\section{Research Study Scenario}

This study analyses the basic digital competencies of 490 first-year university students in two degrees at the Universidad Pablo de Olavide in Seville (Spain). The data were obtained by means of the questionnaire called "Basic digital competences 2.0 of university students" COBADI ${ }^{\circledR}$ (Registered trademark: 2970648). This was created and tested by researchers from the EduInnovagogía ${ }^{\circledR}$ research group (HUM-971) and was implemented through an online questionnaire: https://bit.ly/2plaKVh. It is also translated into several languages (English, Portuguese, Italian, French, among others).

This didactic instrument was applied to university students at the beginning of the first session of the Practical Teaching and Development classes (EPD) in two subjects: "Information and Communication Technologies in Social Education", in the computer classrooms (Figure 1), both corresponding to the first year of the degree in Social Education and the Double Degree in Social Education and Social Work of the Faculty of Social Sciences of the University Pablo de Olavide, in Seville (Spain) with a load of 7.3 ECTS credits (European Credit Transfer System), or those who could not do so who implemented it in their homes. 


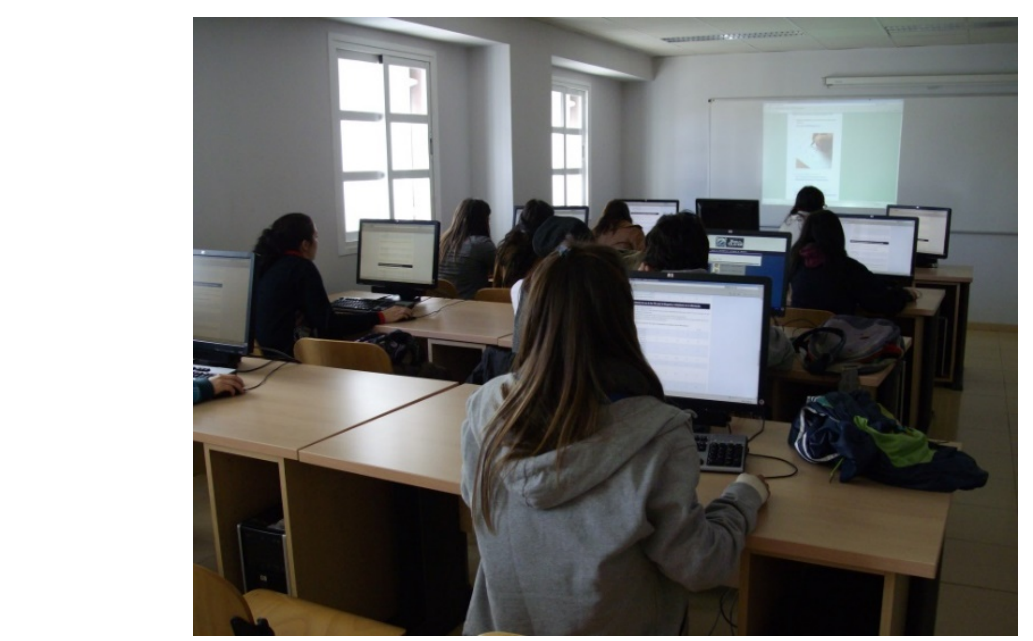

Figure 1. University students doing the COBADI ${ }^{\circledR}$ at the University Pablo de Olavide, Seville (Spain).

\section{Methods}

The research design is non-experimental, describing the links between aspects that have not been directly manipulated (McMillan and Schumacher, 2010).

The general objective of this research is to analyze the basic digital competencies of students. Specifically, the specific objectives of this study are the following:

a. To analyze the distribution of navigation time of university students at the Universidad Pablo de Olavide in the subject "ICT and Social Education", during the academic years 2013/14 to 2016/17

b. Investigate the place of connection of the university student surveyed.

c. Determine the time spent on the Internet by the student body for the four academic years.

The sample is made up of a total of 490 students ( $88.36 \%$ women) in their first year at University, with an average age of 20.45 years $(\mathrm{SD}=4.46)$ who answered the COBADI 2.0 questionnaire in four consecutive years (Table 1). The questionnaire was digitally delivered to participants who were studying Social Education and Social Work (Universidad Pablo de Olavide) from the academic year 2013/14 to 2016/17 in a total of four different courses and there were no restrictions on participation, nor were any financial or academic incentives offered to participate in this study. 


\begin{tabular}{c|c|c|c|c|c|}
\multicolumn{1}{c}{} & \multicolumn{1}{c}{$\mathbf{1 3 / 1 4}$} & $\mathbf{1 4 / 1 5}$ & $\mathbf{1 5 / 1 6}$ & $\mathbf{1 6 / 1 7}$ & \multicolumn{1}{c}{ Total } \\
\cline { 2 - 6 } Women & 131 & 98 & 99 & 105 & 433 \\
\cline { 2 - 6 } Men & 17 & 11 & 17 & 12 & 57 \\
\cline { 2 - 6 } & & & & & \\
& & & & &
\end{tabular}

Table 1. Number of participants by gender and course. Source: Own elaboration

The data was collected by means of the questionnaire called: "Digital Basic Competencies 2.0 of University Students" COBADI®) (Registered trademark: 2970648). Link: https://bit.ly/2plaKVh

The questionnaire was distributed digitally during the academic years 2012/13 to 2016/17, of the first year of the Universidad Pablo de Olavide by means of a non-probabilistic convenience sampling. The questions were related to basic digital competencies. Specifically, it contains 23 items distributed in three categories. The first one refers to "the Competences in the use of ICT for the search and treatment of information", that is, it refers to the individual competence in the use of several technological tools, being this the module analyzed in this research. This module is made up of 11 items that are evaluated through a 1-4 point Likert scale, where 1 refers to "I feel completely ineffective in doing what is presented" up to 4, "I feel completely effective". In addition, it presents the option NS/NC/NA (in case you do not know the answer to the question, or if it is not applycable to the question requested). The second category: "Interpersonal skills in the use of ICT in university scenarios" with 8 items, evaluates how a student solves his/her doubts and problems related to ICT; and the third category, "Virtual and social communication tools of the University", includes questions about the students' use of the University's own electronic platforms.

In the first classes of the course on ICT and Social Education, all students were invited to complete this questionnaire. Their participation was voluntary, but the information they would be asked about would be worked on throughout the academic year, so most of them decided to participate.

The statistical analysis focused on how the students use the technologies and how they perceive their capacity in terms of the COBADI ${ }^{\circledR}$ modules. This analysis was carried out using the SPSS version 12 program. Gender and course differences, both as independent variables, were analyzed through a multiple analysis of variance (MANOVA), with questionnaire responses being the dependent variables in this case.

In the analyses, the Likert scale responses were treated as an interval scale and distributed continuously (Lubke \& Muthen, 2004; Richards, Magee \& Artino, 2012). Homoscedasticity was demonstrated with Levene's F test. Snedecor's F-test was replaced by Welch's F-test when the previous assumptions were not met. Partial Stage 2 was calculated as an index of the effect size in all cases, and was evaluated according to Cohen's conventional 
levels (Cohen, et al., 2013), which were understood as small when they were $<.30$, medium when it was between .30 and .49 , and high when it was $\geq .50$.

\section{Results}

Regarding the results of the first question of COBADI®: "How much time do you spend surfing the Internet? No statistically significant differences were obtained between the courses, considering the number of hours per week that they are connected to the Internet $(p=0.25)$. All the groups showed a similar profile, represented in figure 1. As can be seen, for any of the years, nobody claimed to spend more than one hour a week connected. More than half of the people surveyed said they were connected for more than 9 hours a week.

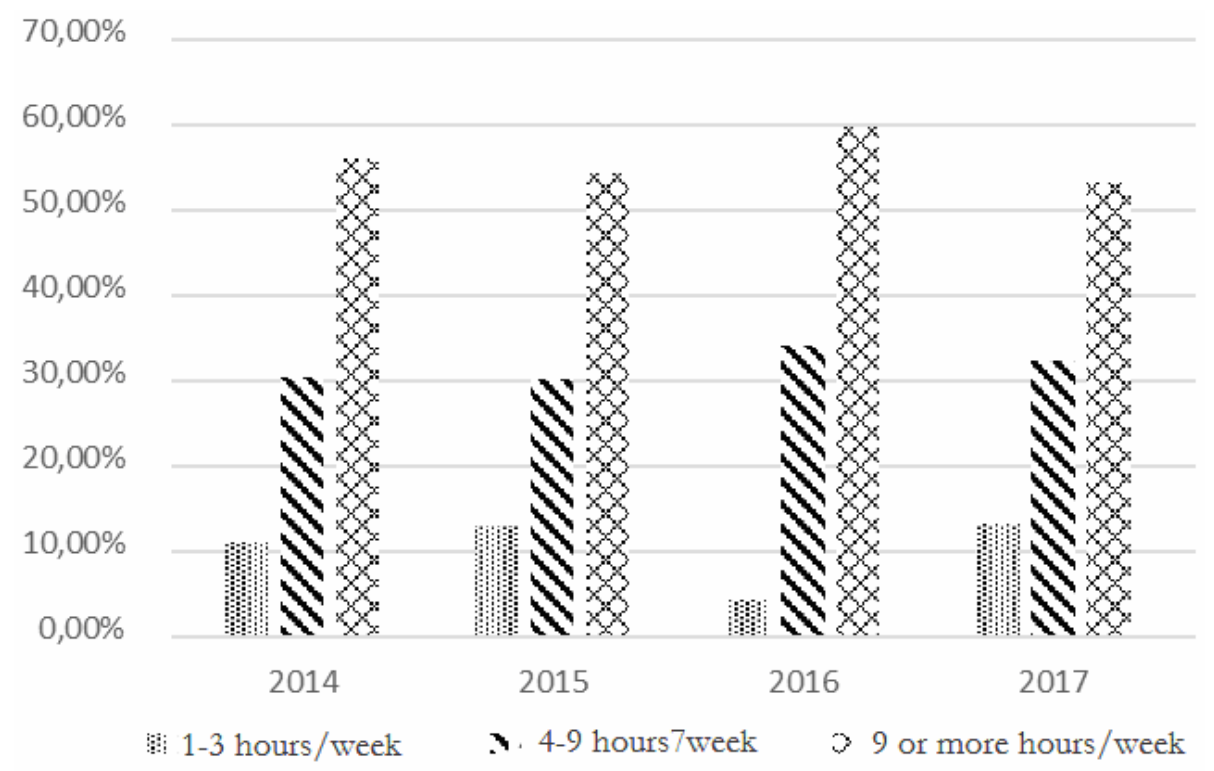

Figure 1. Answers to the question: How much time do you spend surfing the Internet? [per year]. Source: Own elaboration

The second question was "Where do you usually connect to the Internet? Of the total of 490 responses received, only 3 indicated that they usually connect from a library or other public place, and 13 indicated that they usually connect to the University network. Therefore, we decided to eliminate these responses and analyze only the changes that occur in the two main categories: at home and on the mobile phone itself.

As can be seen in Figure 2, there has been an interesting and gradual change in recent years in terms of the place of connection to the Internet, from the home as the main place of connection to the mobile phone as the most 
frequent means. It can be clearly seen that this proportion has reversed in recent surveys, and now reflects the majority use of smartphones to perform many functions on the Internet on a daily basis. Several of the activities carried out by student teachers preferred the use of mobile phones to the laptop distributed free of charge by educational policy. In turn, other research (Liu et al. 2014; Vázquez-Cano, 2014; Vázquez-Cano et al., 2016; Major, Hassler \& Hennessy, 2017; Cabero \& Barroso, 2018) shows the interest and motivation of students in the use of mobile devices in educational settings and their implications for student learning outcomes.

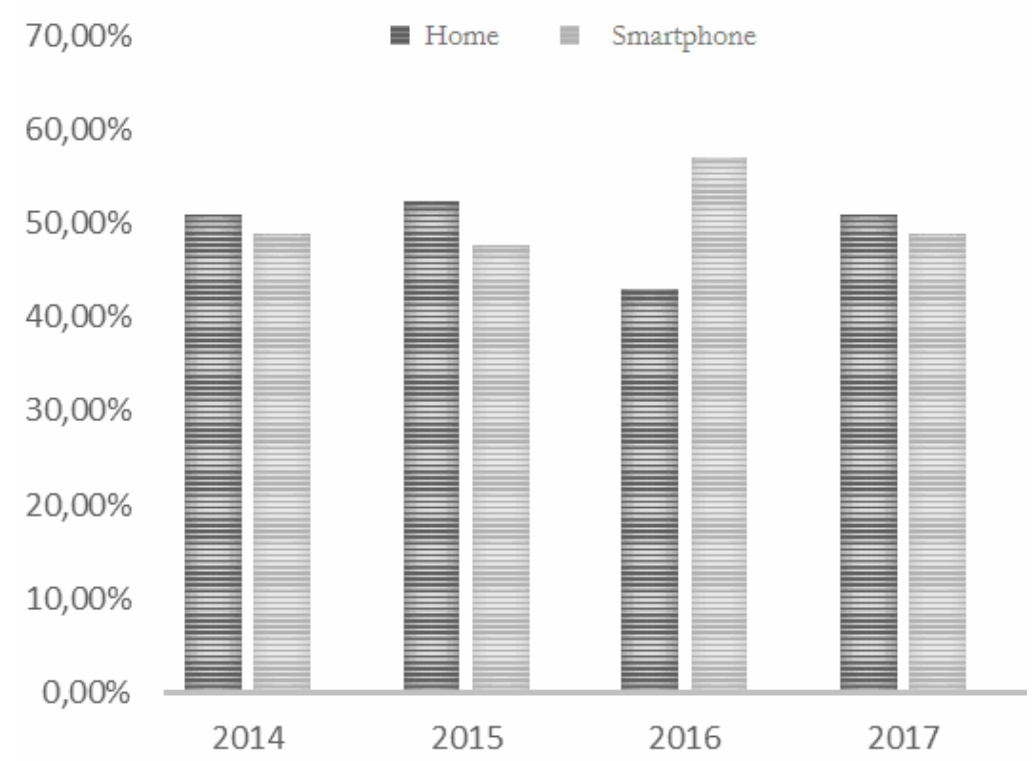

Figure 2. Answers to the question: Where do you usually connect to the Internet? [per year]. Source: Own elaboration

Thirdly, the relationship between time spent on different Internet activities with gender and academic year as main factors was analysed. Table 2 shows all the answers to these ten questions by year and gender, and Table 3 shows the statistical results obtained after performing the multiple analysis of variance.

\begin{tabular}{|l|l|r|r|r|r|}
\hline & Year & $\mathbf{2 0 1 4}$ & $\mathbf{2 0 1 5}$ & $\mathbf{2 0 1 6}$ & $\mathbf{2 0 1 7}$ \\
\hline \multirow{3}{*}{ Watching TV } & Women & 1.82 & 1.98 & 2.03 & 2.14 \\
\cline { 2 - 6 } & Men & 1.76 & 1.94 & 2.00 & 2.08 \\
\hline \multirow{2}{*}{ Listening to music } & Women & 2.59 & 2.72 & 2.81 & 2.72 \\
\cline { 2 - 6 } & Men & 2.71 & 2.59 & 3.00 & 2.83 \\
\hline
\end{tabular}


Juan David Concepción Rosa, María Guadalupe Veytia Bucheli, José Gómez Galán, \& Eloy

López Meneses, International Journal of Educational Excellence, (2019) Vol. 5, No. 2, 47-64. ISSN 2373-5929

DOI: $10.18562 /$ IJEE.048

\begin{tabular}{|l|l|l|l|l|l|}
\hline Looking for information & Women & 2.62 & 2.63 & 2.56 & 2.63 \\
\cline { 2 - 6 } & Men & 2.41 & 2.41 & 2.14 & 2.83 \\
\hline \multirow{2}{*}{ Playing } & Women & 1.31 & 1.16 & 1.18 & 1.17 \\
\cline { 2 - 6 } & Men & 1.53 & 1.18 & 1.43 & 1.67 \\
\hline \multirow{2}{*}{ Doing homework } & Women & 2.90 & 2.86 & 2.83 & 2.87 \\
\cline { 2 - 6 } & Men & 2.82 & 2.71 & 2.14 & 2.35 \\
\hline \multirow{2}{*}{ Sharing photos } & Women & 2.39 & 2.42 & 2.52 & 2.47 \\
\cline { 2 - 6 } & Men & 2.06 & 2.29 & 2.43 & 2.17 \\
\hline \multirow{2}{*}{ Downloading } & Women & 2.20 & 2.09 & 2.27 & 2.20 \\
\cline { 2 - 6 } & Men & 2.41 & 2.24 & 2.43 & 2.42 \\
\hline \multirow{2}{*}{ Talking to friends } & Women & 2.67 & 2.82 & 2.81 & 2.88 \\
\cline { 2 - 6 } & Men & 2.53 & 2.71 & 3.00 & 2.67 \\
\hline \multirow{2}{*}{ Looking for friendships } & Women & 2.06 & 1.88 & 1.94 & 1.97 \\
\cline { 2 - 6 } & Men & 1.65 & 1.88 & 1.43 & 1.92 \\
\hline \multirow{2}{*}{ Working } & Women & 2.63 & 2.46 & 2.62 & 2.68 \\
\cline { 2 - 6 } & Men & 2.35 & 2.29 & 2.00 & 2.67 \\
\hline
\end{tabular}

Table 2. Answers to the question "How much time do you spend on the Internet in the following activities" by year and gender. Source: Own elaboration

\begin{tabular}{|l|r|c|c|c|c|c|c|c|c|c|c|c|}
\hline \multirow{2}{*}{ Activities } & \multicolumn{4}{|c|}{ Year } & \multicolumn{4}{|c|}{ Gender } & \multicolumn{3}{c|}{ Year and Gender } \\
\cline { 2 - 14 } & df & F & Sig. & $\mathrm{R}^{2}$ & df & F & Sig. & $\mathrm{R}^{2}$ & df & F & Sig. & $\mathrm{R}^{2}$ \\
\hline Watching TV & 6 & 1.85 & .088 & .015 & 1 & 0.77 & .380 & 0.00 & 6 & 0.41 & .870 & 0.00 \\
\hline Listening to music & 6 & 4.26 & $.000^{*}$ & .033 & 1 & 0.46 & .500 & 0.00 & 6 & 1.00 & .426 & 0.01 \\
\hline Looking for information & 6 & 1.82 & .092 & .014 & 1 & 4.11 & .043 & 0.01 & 6 & 2.00 & .063 & 0.02 \\
\hline Playing & 6 & 5.10 & $.000^{*}$ & .039 & 1 & 44.44 & $.000^{*}$ & 0.06 & 6 & 3.01 & $.007^{*}$ & 0.02 \\
\hline Doing homework & 6 & 5.76 & $.000^{*}$ & .044 & 1 & 25.12 & $.000^{*}$ & 0.03 & 6 & 4.03 & $.001^{*}$ & 0.03 \\
\hline Sharing photos & 6 & 0.93 & .473 & .007 & 1 & 15.80 & $.000^{*}$ & 0.02 & 6 & 0.51 & .800 & 0.00 \\
\hline Downloading & 6 & 0.51 & .801 & .004 & 1 & 0.74 & .390 & 0.00 & 6 & 0.37 & .901 & 0.00 \\
\hline Talking to friends & 6 & 2.13 & $.048^{*}$ & .017 & 1 & 3.50 & .062 & 0.00 & 6 & 1.13 & .343 & 0.01 \\
\hline Looking for friendships & 6 & 1.40 & .211 & .011 & 1 & 8.93 & $.003^{*}$ & 0.01 & 6 & 0.87 & .515 & 0.01 \\
\hline Working & 6 & 2.39 & $.027^{*}$ & .019 & 1 & 14.78 & $.000^{*}$ & 0.02 & 6 & 1.61 & .140 & 0.01 \\
\hline
\end{tabular}

Table 3. Statistical results for MANOVA with gender and course as independent variables.

Source: Own elaboration

Significant differences were found according to the year evaluated for the activities "listening to music", "talking to friends" and "working", as shown in Figure 3. In the first two, there seems to be a gradual increase as the years go by, being clearer in the first one. On the other hand, in academic activity, although clear differences were observed from one year to the next, the downward trend breaks with a peak in 2017. In this sense, it is estimated that it is not possible to extract totally conclusive results, beyond the fact that there have been differences in the amount of time dedicated to work according 
to the year evaluated. Finally, the activities of playing and carrying out academic tasks, although they showed significant differences for the year variable, also did so in their interaction with gender, so this is considered a relevant analysis that will be described later.

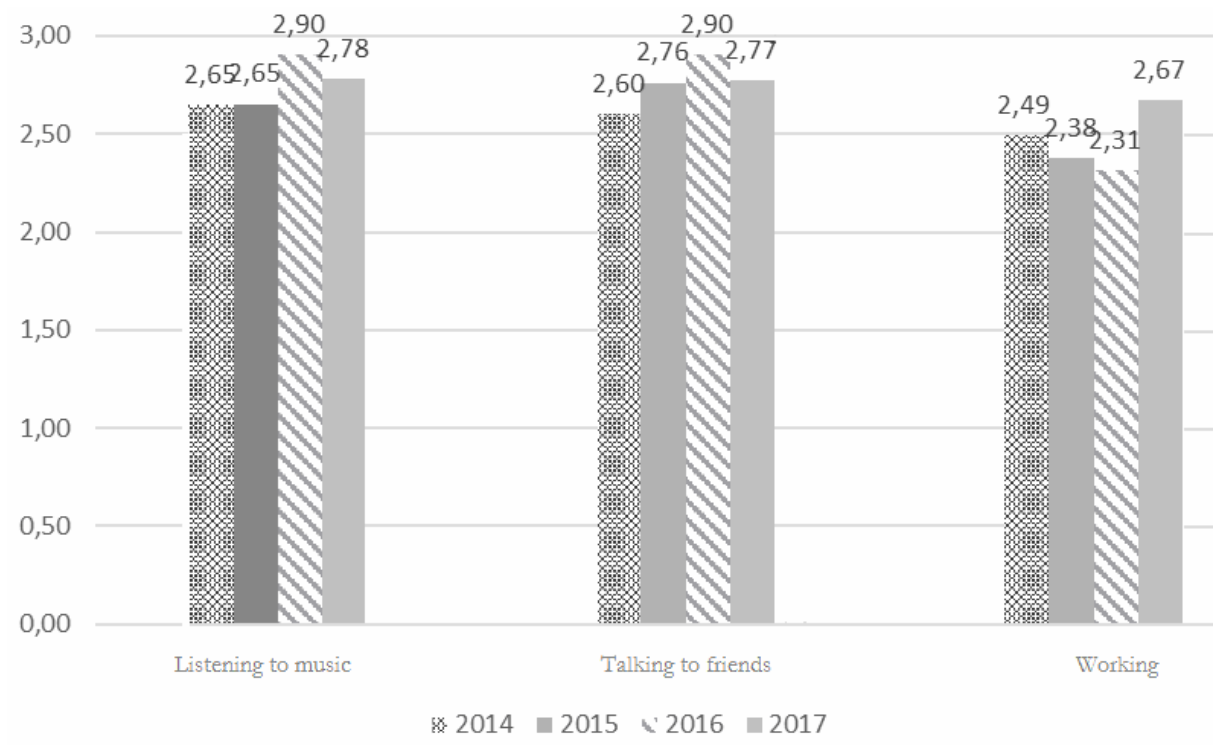

Figure 3. Time spent on the Internet by year. Source: Own elaboration

In turn, as shown in Figure 4, in those activities where significant differences between men and women were observed (sharing photos and videos, seeking friendships and working), it was always the women who scored highest. In this sense, it is corroborated by the research of Fernandez and Neri (2013) who indicated that $50 \%$ of their university population connected to the Internet every day, mainly to chat $(76.4 \%)$, un-load movies and music (52\%) and study (32.6\%). Similarly, the survey of the "Asociación para la Investigación de Medios de Comunicación" (AIMC) (2018) conducted to Spanish Internet users, identified that users over fourteen years old use the mobile phone as the main device for Internet access and that more than $40 \%$ surf the Internet more than 4 hours a day. 


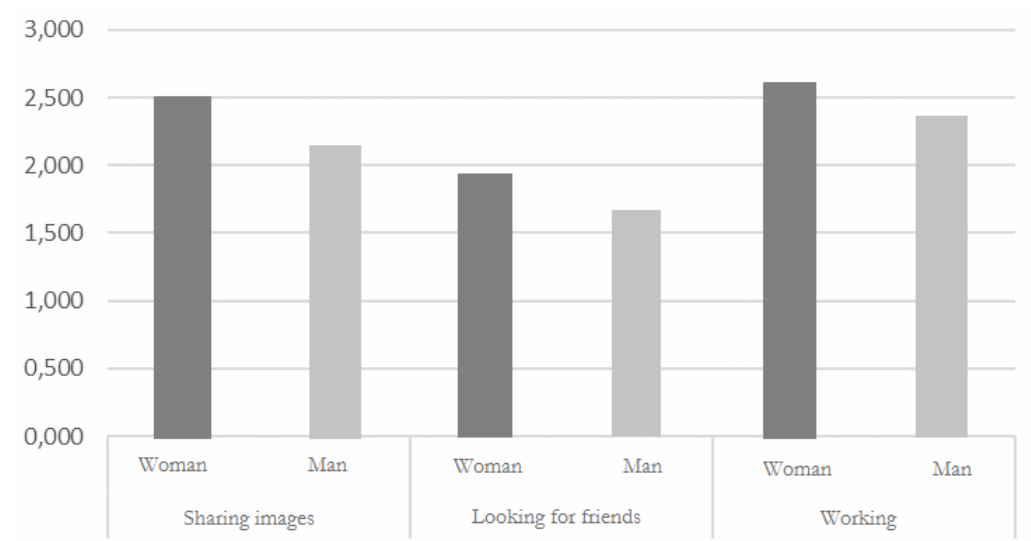

Figure 4. Time spent on the Internet by gender. Source: Own elaboration

Finally, Figure 5 presents the results of the interaction between gender and course during the time spent playing and performing tasks on the Internet. As can be seen, in both cases there has been a distancing between men and women as the years have gone by. Although women have remained constant in the time dedicated to both activities, in men we can see a decrease in the time dedicated to academic tasks and an increase in the time dedicated to playing. In this sense, other studies describe the emergence of addictive behaviours as a result of excessive use in the educational and personal sphere (Castellana et al., 2007; Cuesta \& Gaspar, 2013; Rodríguez-Gómez et al., 2018).

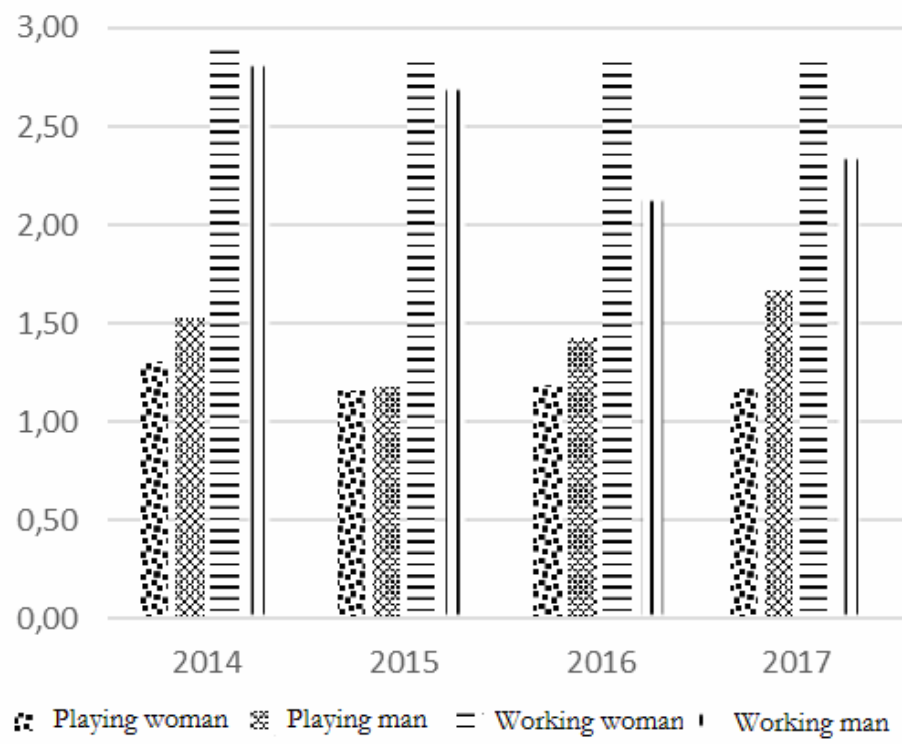

Figure 5. Time spent playing and working on academic tasks by year and gender. Source: Own elaboration 


\section{Discussion and Conclusions}

The 21 st century is the century of information where individual learning is conceived mainly through interactive and participatory technologies that offer a stimulating and socially positive experience, but which, at the same time, become a construct that allows students to learn by doing, while sharing their knowledge experiences with others who are often on the other side of that virtual space (Warren, et. al. 2017). Technology, as a fundamental ingredient for the advancement of the Knowledge Society, has assumed a fundamental role in the educational environment (Ciolan, et al., 2014; Linuma, 2015).

Training, research and technological innovation are the main axes for improving the quality and competitive-ness of a country, as well as the sustainable development of its citizens (López-Meneses \& Vázquez-Cano, 2013; López-Meneses, 2017). In this sense, the universities should adapt the training processes attending, among other aspects, to the current characteristics and needs of the students, facilitating the incorporation of flexible scenarios for training and where they are aware of their own training process in the acquisition of competences and skills (Cabero, Ballesteros and LópezMeneses, 2015).

Regarding the diachronic research carried out with the surveyed first entrance university students, it is inferred that more than half of the students indicated that they connected more than 9 hours a week, that the usual place of connection is through the mobile phone and, in addition, of carrying out academic tasks, mainly in-formation search, use of the virtual classroom and academic contents, they use the mobile phone more to "listen to music" and "talk with friends". In this sense, it coincides with the report prepared by the group be-longing to the National Observatory of Telecommunications and the Information Society (Muñoz-López and Antón-Martínez, 2017, p. 21), which states: "[...], as a general guideline, the use of digital content is more present among young people and decreases as age increases. With regard to all content, young people between 16 and 24 are the consumers who mostly watch digital photos, use social networks, watch audiovisual content, listen to music, and play video games". Finally, it is worth noting a worrying rise in men in the time dedicated to playing digital video games, where they are investing time in this activity and have neglected the performance of university activities and tasks, as well as decreasing the quality of the work they present.

According to Cabero et al. (2015), the Internet is emerging as one of the technologies with the greatest impact on university penetration, with students using it permanently for educational purposes. There-fore, it is necessary to emphasize the need for current university institutions to establish adequate 
conditions to promote a more student-centered learning, with the use of innovative teaching methods, training critical and active citizens, willing to put their knowledge at the service of society (Santos, et al. 2017) in symbiosis with ICTs to facilitate the communicative interaction of the university community, the approach to content from multiple perspectives and the creation of flexible and enriched learning environments, in addition, without for-getting that priority should always be given to the pedagogical and technological aspects for adequate curricular integration in the classroom (Cabero et al, 2015).

Ultimately, we believe that the training of university students focused on digital competence is necessary to enable students to become digital dynamizers and techno-proactive agents for the sustainable development of the Digital Global Society, as well as possessing the necessary skills to respond effectively and efficiently to the demands of 21 st century society.

Acknowledgements: The study arises from the guideline marked by the project "Teaching Innovation 2.0. with ICT in the European Higher Education Area", financed by the Pablo de Olavide University (UPO) and under the supervision of the researchers of the Eduinnovagogía $($ Research Group (HUM-971). Group recognized by the Andalusian Plan for Research, Development and Innova-tion and the Office for the Transfer of Research Results of the Universidad Pablo de Olavide in Seville, Spain.

\section{References}

Asociación para la Investigación de Medios de Comunicación. (2018). Encuesta a usuarios de Internet. Infografia, Resumen 21: octubre a diciembre 2018. Retrieved from https://bit.ly/2TPXtN3

Atif, Y., Mathew, S. S., \& Lakas, A. (2015). Building a Smart Campus to Support Ubiquitous Learning. Journal of Ambient Intelligence and Humanized Computing, 6(2), 223-238. doi: 10.1007/s12652-014-0226-y

Blau, I., \& Shamir-Inbal, T. (2017). Digital Competences and Long-Term ICT Integration in School Culture: The Perspective of Elementary School Leaders. Education and Information Technologies, 22(3), 769-787. doi: 10.1007/s10639-015-9456-7

Bozkurt, A., Honeychurch, S., Caines, A., Bali, M., Koutropoulos, A., \& Cormier, D. (2016). Community Tracking in a cMOOC and Nomadic Learner Behavior Identification on a Connectivist Rhizomatic Learning Network. Turkish Online Journal of Distance Education, 17(4), 4-30. doi: $10.17718 /$ tojde. 09231

Cabero, J. (2015). Reflexiones educativas sobre las tecnologías de la información y la comunicación (TIC). Tecnología, Ciencia y Educación, $1,19-27$. 
Cabero, J. \& Ruiz-Palmero, J. (2018). Las Tecnologías de la Información y Comunicación para la inclusión: reformulando la brecha digital. IJERI: International Journal of Educational Research and Innovation, 9, 1630.

Cabero, J., Ballesteros C. \& López-Meneses, E. (2015). Los mapas conceptuales interactivos como recursos didácticos en el ámbito universitario. Revista Complutense de Educación, 26, 51-76.

Cabero, J., \& Barroso, J. (2018). Los escenarios tecnológicos en Realidad Aumentada (RA): posibilidades educativas en estudios universitarios. Aula Abierta, 47(3), 327-336.

Castao, J., Duart, J., \& Teresa, S. V. (2015). Determinants of Internet Use for Interactive Learning: An Exploratory Study. Journal of New Approaches in Educational Research, NAER, 4(1), 24-31.

Castellana, M., Sánchez-Carbonell, X., Jordana, C. G., \& Fargues, M. B. (2007). El adolescente ante las tecnologías de la información y la comunicación: Internet, móvil y videojuegos. Papeles Del Psicólogo, 28(3), 196-204.

Ciolan, L., Petrescu, A., Radulescu, C., \& Bucur, C. (2014). Training Teachers to Use Digital Resources for the Knowledge Society. Procedia-Social and Behavioral Sciences, 128(22), 415-419. doi: 10.1016/j.sbspro.2014.03.180

Cobo, C., \& Moravec, J. (2011). Introducción al aprendizaje invisible: la (r)evolución fuera del aula. Reencuentro. Análisis de Problemas Universitarios, 62, 66-81.

Cohen, J., Cohen, P., West, S. G., \& Aiken, L. S. (2013). Applied Multiple Regression/Correlation Analysis for the Behavioral Sciences. New York: Routledge.

European Commision (2006). Competencias clave para el aprendizaje permanente. Recomendación 2006/962/CE del Parlamento Europeo y del Consejo, de 18 de diciembre de 2006, sobre las competencias clave para el aprendizaje permanente [Diario Oficial L 394 de 30.12.2006]

Cuesta, U., \& Gaspar, S. (2013). Análisis motivacional del uso del smartphone. Historia y Comunicación Social, 18, 435-447

Durán, M., Prendes, M. P., \& Gutiérrez, I. (2019). Teaching Digital Competence Certification: a proposal for university teachers. RIEDRevista Iberoamericana de Educacion A Distancia, 22(1), 187-205.

Erstad, O., \& Voogt, J. (2018). The Twenty-First Century Curriculum: Issues and Challenges. In J. Voogt, G. Knezek, R. Christensen, \& K.W. Lai (eds.), Second Handbook of Information Technology in Primary and Secondary Education, (pp. 19-36). Cham: Springer.

Fombona, J., \& Pascual, M. Á. (2017). La producción científica sobre Realidad Aumentada, un análisis de la situación educativa desde la perspectiva SCOPUS. EDMETIC, 6(1), 39-61. 
Gómez Galán, J. (2011). New Perspectives on Integrating Social Networking and Internet Communications in the Curriculum. eLearning Papers, 26, 1-7.

Gómez Galán, J. (2014). Transformación de la Educación y la Universidad en el Postmodernismo Digital: Nuevos Conceptos Formativos y Científicos. In F. Durán (ed.). La Era de las TIC en la Nueva Docencia (pp. 171-182). Madrid: McGraw-Hill.

Gómez Galán, J. (2002). La Integración de la Telemática en la Escuela. Revista Latinoamericana de Tecnología Educativa, 1(2), 47-59.

Gómez Galán, J. (2017). Interacciones Moodle-MOOC: Presente y Futuro de los Modelos de e-Learning y b-Learning en los Contextos Universitarios, Eccos Revista Científica, 44, 17-31. doi: 10.5585/eccos. n44.7353

Gómez Galán, J. \& Mateos, S. (2004). Design of Educational Web Pages. European Journal of Teacher Education, 17(1), 99-107. doi: 10.1080/ 0261976042000211793

González Calatayud, V., Román, M., y Prendes, M.P. (2018). Formación en competencias digitales para estudiantes universitarios basada en el modelo DigComp. Edutec. Revista Electrónica de Tecnología Educativa, 65, 1-15. doi:https://doi.org/10.21556/edutec.2018.65.1119

González, J. \& Wagenaar, R. (eds.) (2006). Tuning Educational Structures in Europe. Retrieved from http://www.unideusto.org/tuningeu/images/ stories/publications/tuning_2_cast_pr2_pdf.pdf

González-Aldana, M. A., Perdomo, K. V., \& Pascuas, Y. (2017). Application of ICT in Blended Learning Educational Models: A Systematic Review of Literature. Sophia, 13(1), 144-154.

Gutiérrez-Porlán, I. (2014). Perfil del profesor universitario español en torno a las competencias en tecnologías de la información y la comunicación. Pixel-Bit, Revista de Medios y Educación, 44, 51- 65. doi: 10.12795/ pixelbit.2014.i44.04.

Hernández Pina, F., Martínez Clares, P., Martínez Juárez, M. \& Monroy, F. (2009). Aprendizaje y competencias. Una nueva mirada. Revista Española de Orientación y Psicopedagogía, 20(3), 312-319.

Hinostroza, J.E. (2017). TIC, educación y desarrollo social en América Latina y el Caribe. Montevideo: UNESCO.

Kormos, J., \& Csizer, K. (2014). The Interaction of Motivation, SelfRegulatory Strategies, and Autonomous Learning Behavior in Different Learner Groups. Tesol Quarterly, 48(2), 275-299. doi: 10.1002/tesq.129

Krücken, G. (2014). Higher Education Reforms and Unintended Consequences: A Research Agenda. Studies in Higher Education, 39(8), 1439-1450. doi: 10.1080/03075079.2014.949539

Laskaris, D., Kalogiannakis, M., \& Heretakis, E. (2017). Interactive Evaluation of an e-Learning Course within the Context of Blended 
Education. International Journal of Technology Enhanced Learning, 9(4), 339-353. doi: 10.1504/ijtel.2017.10006470

Le Boterf, G. (2000). La ingeniería de las competencias. Barcelona: Gestión 2000.

Liu, M., Scordino, R., Geurtz, R., Navarrete, C., Ko, Y., \& Lim, M. (2014). A Look at Research on Mobile Learning in K-12 Education from 2007 to the Present. Journal of Research on Technology in Education, 46(4), 325-372. doi:10.108 0/15391523.2014.925681

Linuma, M. (2015). Learning and Teaching with Technology in the Knowledge Society: New Literacy, Collaboration and digital Content. New York: Springer.

López-Meneses, E. (2017). El fenómeno MOOC y el futuro de la universidad. Fronteras de la Ciencia, 1, 90-97. doi: 10.18562/fdlc0014

López-Meneses, E. \& Vázquez-Cano, E. (2013). WEB 2.0 Tools for Social Educator Training in Higher Education. International Journal of Research in Social Sciences, 3(2), 1-13.

Lubke, G. H., \& Muthén, B. O. (2004). Applying Multigroup Confirmatory Factor Models for Continuous Outcomes to Likert Scale Data Complicates meaningful Group Comparisons. Structural Equation Modeling, 11(4), 514-534.

Maquilón, J. J., Mirete, A. B., \& Avilés, M. (2017). La Realidad Aumentada (RA). Recursos y propuestas para la innovación educativa. Revista Electrónica Interuniversitaria de Formación del Profesorado, 20(2), 183-204.

Major, L., Hassler, B., \& Hennessy, S. (2017). Tablets in Schools: Impact, Affordances and Recommendations. In A. Marcus-Quinn \& T. Hourigan (Eds.). Handbook for Digital Learning in K-12 Schools (pp. 115-128). Cham: Springer.

Marathe, R. (2017). Role of ICT in Higher Education in Global Era. International Journal on Recent and Innovation Trends in Computing and Communication, 5(11), 44-46.

Mbati, L. (2017). Creating Awareness around Rhizomatic Principles in mLearning: A Means to Improving Practice. International Journal of Mobile and Blended Learning, 9(2), 74-87.

Muñoz López, L \& Antón-Martínez (2017). Estudio de uso y actitudes de consumo de contenidos digitales. Observatorio nacional de las telecomunicaciones y de la sociedad de la información. Retrieved from https://bit.ly/2xS9h2x

OECD (2018). The future of education and skills. Education 2030. Retrieved from http://go.uv.es/1fDpQnn.

Prendes, M. P. (ed.) (2010). Competencias TIC para la docencia en la universidad pública española: Indicadores y propuestas para la definición de buenas prácticas: Programa de Estudio y Análisis. Informe 
del Proyecto EA-2009-0133 de la Secretaría de Estado y Universidades e Investigación. Madrid: MEC.

Rickards, G., Magee, C., \& Artino, A. R. (2012). Developing Survey Instruments and Collecting Validity Evidence. Journal of Graduate Medical Education, 4(4), 407-410.

Riis, S. (2017). ICT Literacy: An Imperative of the Twenty-First Century. Foundations of Science, 22(2), 385-394.

Rodríguez, A. M., Cáceres, M. P., \& Alonso, S. (2018). La competencia digital del futuro docente: análisis bibliométrico de la productividad científica indexada en Scopus. International Journal of Educational Research and Innovation. IJERI, 10, 317-333.

Rodríguez-Gómez, D., Castro, D., \& Meneses, J. (2018). Problematic Uses of ICTs among Young People in Their Personal and School Life. Comunicar, 56, 91-100. doi:10.3916/C56-2018-09

Romero, M., \& Patiño, A. (2018). Usos pedagógicos de las TIC: del consumo a la co-creación participativa. Revista Referencia Pedagógica, 6(1), 215.

San Martín, V. (2010) Formación basada en competencias: historia y perspectivas de futuro. Revista Electrónica de Desarrollo de Competencias (REDEC) 1(5), 7-28.

Santos, M. A., Sotelino, A., Jover, G., Naval, C., Álvarez, J. L., \& Vázquez, V. (2017). Diseño y validación de un cuestionario sobre práctica docente $\mathrm{y}$ actitud del profesorado universitario hacia la innovación (CUPAIN). Educación XX1, 20(2), 39-71. doi: 10.5944/educxx1.19031

Schwab, K. (2016). La cuarta revolución industrial. Barcelona: Editorial Debate.

Tejada, J. (2013). Professionalisation of Teaching in Universities: Implications from a Training Perspective. International Journal of Educational Technology in Higher Education, 10(1), 345-358. doi: 10.7238/rusc.v10i1.1471

Torres, C. A., \& Kiss, G. (2016). Perceptions of Students towards ICT Competencies at the University. Informatics in Education, 15(2), 319338. doi: 10.15388/infedu.2016.16

Vázquez-Cano, E. (2014). Mobile Distance learning with Smartphones and Apps in Higher Education. Educational Sciences: Theory \& Practice, 14(4), 1-16. doi: 10.12738/est.2014.4.2012

Vázquez-Cano, E., Sevillano-García, M. L. \& Fombona-Cadavieco, J. (2016). Análisis del uso educativo y social de los dispositivos digitales en el contexto universitario panhispánico. Revista de Investigación Educativa, 34(2), 453-469. doi: 10.6018/rie.34.2.224691

Warren, W. H., Rothman, D. B., Schnapp, B. H., \& Ericson, J. D. (2017). Wormholes in Virtual Space: From Cognitive Maps to Cognitive Graphs. Cognition, 166, 152-163. doi: 10.1016/j.cognition.2017.05.020 
Juan David Concepción Rosa, María Guadalupe Veytia Bucheli, José Gómez Galán, \& Eloy López Meneses, International Journal of Educational Excellence, (2019) Vol. 5, No. 2, 47-64. ISSN 2373-5929

DOI: 10.18562/IJEE.048

() 2019 Concepción Rosa, Veytia Bucheli, Gómez Galán, \& López Meneses, International Journal of Educactional Excellence, Universidad Ana G. Méndez (UAGM). This is an Open Access article distributed under the terms of the Creative Commons Attribution License (http://creativecommons.org /licenses/by/4.0), which permits unrestricted use, distribution, and reproduction in any medium, provided the original work is properly credited. 